\title{
Effect Of Using E-Filling On Quality Of Tax Reporting Services In East Java
}

\author{
Venantya Asmandani ${ }^{1}$, Tree Setiawan Pamungkas ${ }^{2}$, Rachmat Hidayat ${ }^{3}$ \\ Galih Wicaksono $^{4}$, Yeni Puspita ${ }^{5}$, Nurcahyaning Dwi Kusumaningrum ${ }^{6}$, Djoko Susilo ${ }^{7}$ \\ 1,4,5,6 Program Studi Perpajakan \\ ${ }^{2,3}$ Program Studi Administrasi Negara \\ ${ }^{7}$ Jurusan Hubungan Internasional \\ Fakultas Ilmu Sosial dan Ilmu Politik, Universitas Jember, Jl. Kalimantan No. 37, Jember, Jawa Timur
}

Email : vena.mandani@unej.ac.id

\begin{tabular}{|c|c|}
\hline ARTICLE INFO & ABSTRACT \\
\hline $\begin{array}{l}\text { Article history: } \\
\text { Received: } 25 / 01 / 2020 \\
\text { Revised: 01/02/2020 } \\
\text { Accepted: } 13 / 02 / 2020\end{array}$ & $\begin{array}{l}\text { The purpose of this research is to determine the use of e-filling of the quality } \\
\text { of tax Reporting Services partially. This research used quantitative methods } \\
\text { and data analysis methods use SPSS software with simple regression analysis, } \\
\text { which is used to test tested hypotheses, partially, and to see the magnitude of } \\
\text { the coefficient. Based on the results of research and discussion can be } \\
\text { concluded that partial use of e-filling affects the quality of the annual tax } \\
\text { reporting Service, the direction is positif and is proven in analysis of SPSS test } \\
\text { results with a significance value of } 0.037<\text { from } 0.05 \text {. More and more users } \\
\text { of e-filling then increasing the quality of taxation services because the } \\
\text { taxpayer feels comfortable and safe using e-filling for payment and } \\
\text { reporting its exposure. }\end{array}$ \\
\hline Keywords: & \\
\hline
\end{tabular}

Use of e-Filling, Quality of

Service

\section{Introduction}

Government has a role in managing public finances (Boedijono, et al, 2019). Tax is the largest source of income, pursuant to Act No. 28 of 2007 article 1 paragraph 1, the tax is the mandatory contribution to the country owed by the person who is forced by a personal or pushy entity under the law Get rewarded in a direct and used for country for the greatest prosperity of people. Some of the efforts that the Government has done in increasing tax revenues exceed have been targeted by the central government that is The Directorate General of Taxation (DJP) innovates to unite all payment services and reporting under one system namely Application Service Provider (ASP) through the website of DJP Online, which is djponline.pajak.go.id as an electronic SPT service center. The use of e-filing based on Perdirjen number PER-01/PJ/2017 on the delivery of SPT electronically via e-filling. E-Filling aims to improve services to the public by facilitating the reporting of electronic SPT through internet media to the taxpayer. It also respond to the increasing needs of taxpayers in Indonesia by providing better and easier service and can reduce the burden of administration process of tax report using paper that can suppress the cost and time and Accelerate the transaction process and efficiency. In this era, governments denote the spearhead of increasing the quality of local government public services Susilo, D., R. Hidayat, et al. (2018).

E-Filling Program has been implemented since the year 2007 to facilitate and accelerate the annual tax reporting but the use of E-Filling is still not effective to be done by taxpayers. One of the factors is the difficulty of some areas of affordable internet and public ignorance of the E-Filling program so that taxpayer difficulties to conduct annual SPT reporting through e-Filling. An increase in the taxpayer amount with the taxpayer number reporting the annual SPT which uses e-filling is not comparable to the taxpayer's 


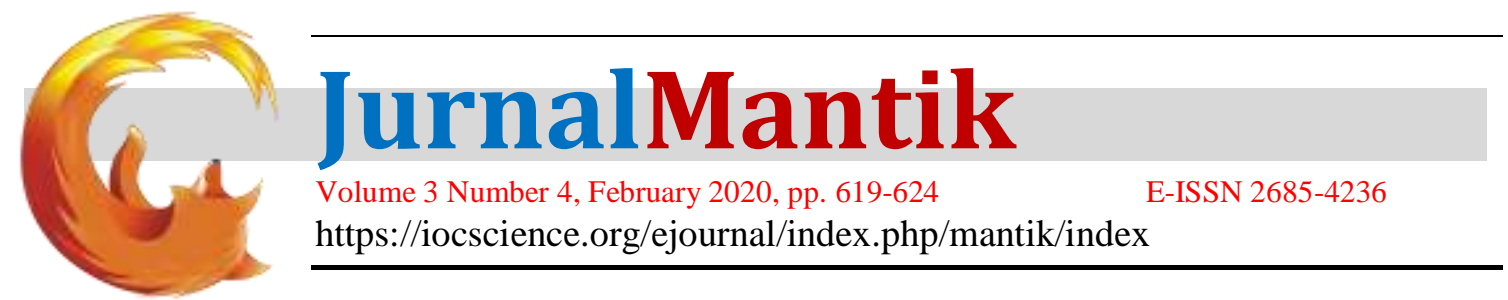

registered amount. It is still a duty for the government to be able to provide knowledge of e filling to the community as a form in improving the quality of tax Reporting Services. The following data on the number of users of e filling in Indonesia from 2015 to 2019 :

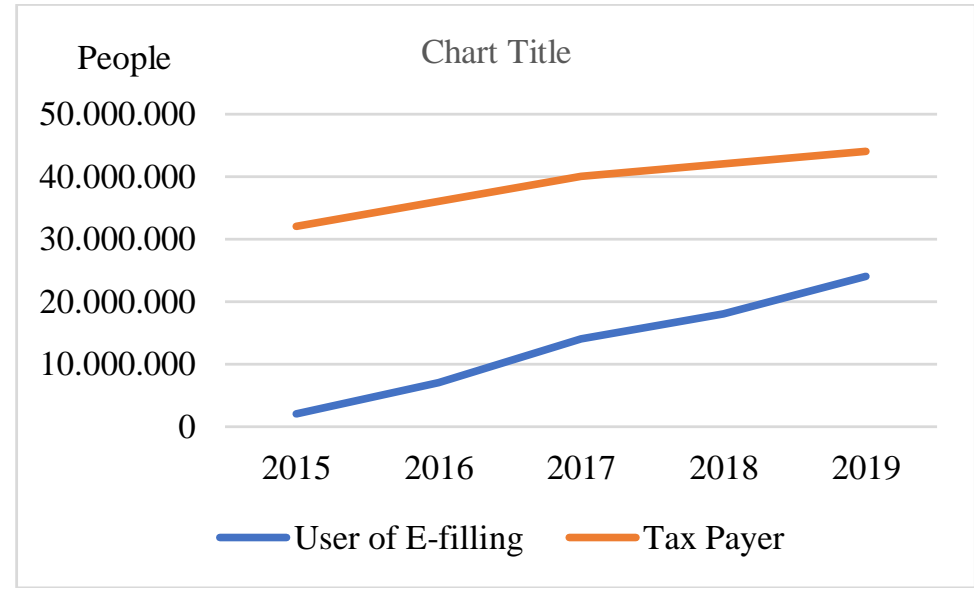

Fig 1. User of e-Filling

Source : Directorate General of Tax Performance Reports, 2020

It can be seen from the one chart that the tax reporting of e-filling is still little than the tax reporting that is done directly by visiting the tax Office. This can be due to several factors that the level of knowledge will still be relatively low efilling and a WiFi network that is less fast than a provider because of the many WP that use network access at the same time (www.nusantaramed.com.id,2018). The problems that often arise regarding the use of e-filing are the lack of taxpayer knowledge on how to use e-filing. Moreover, the use of e-filing is closely related to the taxpayer's ability to operate the computer. So far, the taxpayer knowledge to use the computer is still minimal. Taxpayers prefer to convey SPT by writing rather than typing using computer (Hentriwati et al, 2018:117). Regional Office of the Directorate General tax of Jawa Timur III targeting e-Filling services used as much as 317,314 taxpayers (WP) and as of 29 March 2018 Achievement of E-Filling year 2018 by $73.49 \%$ (www.nusantaramed.co.id,2019). Regional Office of the Directorate General tax of East Java I known the number of SPT we received so far 81,000 taxpayers, consisting of 38,000 taxpayers through e-filling and 43,000 through offline so that users e-Filling in East Java Kanwil I only $46.91 \%$ of the taxpayer's registrant (www.tribunjatim.com, 2018).

E-Filling users in East Java region is still not effective because the taxpayer using e-Filling is still a little, although the benefit of the use of e-filing can facilitate the taxpayer to deliver the SPT effectively and efficiently. Taxpayer does not need to come to the Tax office, for taxpayers who have intensive activity efiling services can also save more time, So the taxpayer does not need to queue to convey SPT and delivery of SPT through e-Filling can be done in realtime, anytime and anywhere. The quality of taxation service is through e-Filling This can improve the quality of service provided by the Government, namely the Directorate General of Taxation. This is reinforced by the research done by Hentriwati et al (2018:128) The increasing number of taxpayers in using efiling, the quality of service will also be better. The results of this research also supported by Saputra 2014 and Gunawan, two studies said that the application of e-filling affects the quality of tax services. The description above then comes the question of whether there is an influence on the use of E-Filing on the quality of service provided by the Directorate General of Taxation in East Java.

\section{Literature Review}

\subsection{Use of E-filling}

Definition of E-Filling according to regulation of the Director general Tax number: PER-26/PJ/2012, E-Filing is a means of delivering the SPT or submission of annual SPT renewal notice electronically conducted on-line that is real time through the Directorate General of Taxation website (www.pajak.go.id) or Application Service Provider (ASP). E-filling is a way of delivering SPT through an on-line and realtime system (Fidel, 2010:56). The application of e-filling system is a process or how to utilize the system 


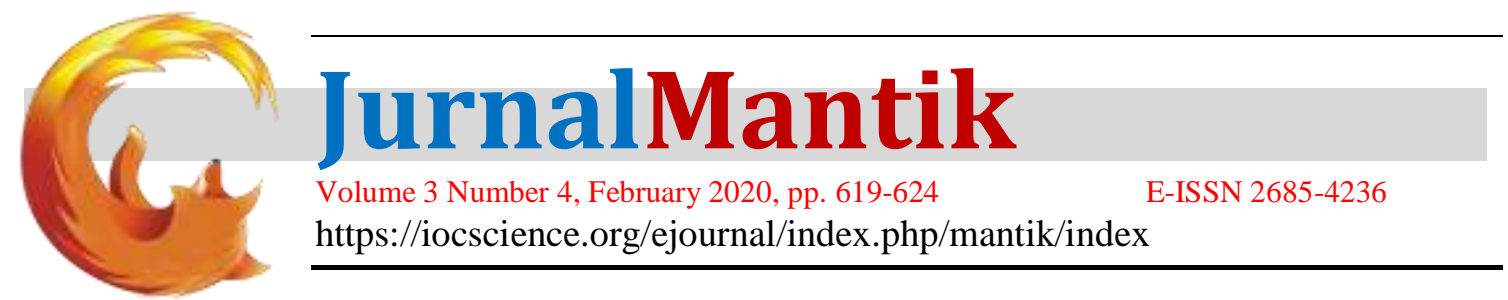

used to deliver the realtime online SPT that is applied by the Directorate General of Taxation. Application of e-filling system has several advantages for taxpayers through DGT site namely:

a) The delivery of the SPT is faster because it can be done anywhere and anytime that is 24 hours a day, 7 days a week because it utilizes Internet network

b) The cost of reporting of the SPT is cheaper because it is free to access the DJP website

c) Calculation is done quickly because it uses a computer system

d) Easier because of the SPT in the form of a wizard

e) Data submitted by taxpayers is always complete because there is a validation of filling the tax return.

f) More environmentally friendly because it minimizes the use of paper.

\subsection{Service Quality E-Filling}

Quality of service is a quality that can not be determined by the service provider and service users have the power to determine whether the service is appropriate, exceed, or not in accordance with the expectation (Kaihatu et al, 2015:29).According to Papadomichelaki and Mentzas (2011) e-Government quality is an approach to measure the extent to which an e-Government website can provide facilities and provide competent services to the E-service efficiency to help Community. According to Lenvinne in Hardiyansyah (2011:53) Dimensions of service quality consist of: responsiveness, responsibility, \& accountability.

a) Responsiveness or this responsiveness measures the responsiveness of service providers in this research Poatnika to the hopes, desires and aspirations and demands of the community service users (e-filling).

b) Responsibility or responsibility is a measure that demonstrates the process of providing public services in this research is the fiscus is the e-filling is done by not violating the provisions that have been set by the government.

c) Accountability or accountability is a measure that indicates the level of conformity between the service in this research is the tax fiscus with external measures that exist in the community, how the efilling is useful appropriate to can facilitate the community.

\section{Research Method}

This research uses quantitative research methods. Variables used in this research, namely the application of e-filling and quality of service. The population in this study is the entire taxpayer of a personal person using e-filling in East Java. As for the samples, that is part of the population that became the object of research. Given the number of private people taxpayers in East Java, the sample selection is conducted in this study. Questionnaires will be sent to the individual taxpayers who have been designated as samples in the study, where each Regency/city in East Java will be sent a research questionnaire to quantitatively analyze data. This research uses SPPS with simple linear regression. The data sources in this study are primary data and secondary data. Primary data is data obtained directly from the respondent, namely in the form of a research questionnaire distributed to respondents, as well as data obtained from the results of interviews with respondents. Variable measurements on questionnaires using a Likert scale with a scale of 1 to 5 , this study also uses secondary data, which is the publication data obtained from an institution or an institution as a data provider. Secondary Data are research journals, related reference books, as well as resources from the Internet. The study used a simple regression analysis test used to determine the influence between variables independent of dependent variables. Regression models in this study can be written as follows:

Description:

$$
Y^{\prime}=a+b X
$$

$\mathrm{Y}^{\prime}=$ Service quality variables

$\mathrm{X}=$ Variable Use e-Filling

$\mathrm{A}=$ constant $(\mathrm{Y}$ value ' when $\mathrm{X}=0$ )

$\mathrm{b}=$ regression coefficient (value of increase or decrease) 


\section{Result and Discussion}

\section{a. Data Analysis Test}

Data analysis test can use the validity test and reliability test (Ghozali, 2016). This validity test is carried out by measuring the significance of 0.05 . Here are the validity test results of the survey instrument data of each variable:

Table 1. Validity Test

\begin{tabular}{cccc}
\hline Research Variable & Item & Sig. & Keterangan \\
\hline Use of E-Filling & 12 & 0,00 & Valid \\
\hline Service Quality E-Filling & 9 & 0,00 & Valid
\end{tabular}

Instruments research are valid when the correlation value (Pearson correlation) is positive, and the probability value of the correlation [sig. (2-tailed)] $<$ is significant $(\alpha)$ of 0.05 . Known data analysis result with its significance value is 0.00 , thus the $<0.05$ so that the question instrument is valid and can be measured.

Reliability test by using Cronbach's Alpha by measuring alpha value between 0.70-0.90 then high reliability. If Alpha is between 0.50-0.70 then moderate reliability. If Alpha $<0.50$ then reliability is low. If Alpha is low, chances are one or more items are not reliable. The following reliability test results:

Table 2. Reliability Test Use e-Filling

\begin{tabular}{ccc}
\hline & & \\
& Cronbach's & \\
& Alpha Based & \\
Cronbach's & on & \\
Alpha & Itandardized & $\mathrm{N}$ of \\
\hline 0,946 & 0,948 & Items \\
\hline
\end{tabular}

\section{Table 3. Reliability Test Service Quality Variables}

\begin{tabular}{ccc}
\hline & Cronbach's & \\
& $\begin{array}{c}\text { Alpha Based } \\
\text { on }\end{array}$ & \\
Cronbach's & $\begin{array}{c}\text { Standardized } \\
\text { Alpha }\end{array}$ & N of \\
Items & Items \\
\hline 0,939 & 0,940 & 9 \\
\hline
\end{tabular}

Thus, based on the reliability test, it can be noted that the proposed variables are included in the perfect classification, with Cronbach Alpha above 0.9

\section{b. Classic Assumption Test}

Test normality tests whether in regression models, independent variables and dependent variables, both of which are distributed normally or not. Tests of normality on this study have been tested by means of the Smyrna Kolmogorov Test (Test KS). Here are the results of the test KS that have been done: 
Table 4. Kolmogorov Smirnov Test

One-Sample Kolmogorov-Smirnov Test

\begin{tabular}{|c|c|c|}
\hline & & $\begin{array}{c}\text { Unstandardized } \\
\text { Residual }\end{array}$ \\
\hline $\mathrm{N}$ & & 125 \\
\hline \multirow[t]{2}{*}{ Normal Parameters ${ }^{\mathrm{a}, \mathrm{b}}$} & Mean &, 0000000 \\
\hline & Std. Deviation & 7,01789280 \\
\hline \multirow[t]{3}{*}{ Most Extreme Differences } & Absolute & ,076 \\
\hline & Positive & 075 \\
\hline & Negative &,- 076 \\
\hline Test Statistic & & ,076 \\
\hline Asymp. Sig. (2-tailed) & &, $071^{\mathrm{c}}$ \\
\hline
\end{tabular}
a. Test distribution is Normal.
b. Calculated from data.
c. Lilliefors Significance Correction.

According to Table 4 test Kolmogorov Smirnov, it can be noted that the magnitude of the Kolmogorov Smirnov value of 0.076 with a significance value of 0.071 where the value is above 0.05 , which means that the residual value is distributed normally.

The heteroskedastisity test aims to test the presence of unequal variance disorders. Testing heteroskedastisity using Scatterplot graphs. The following results of heteroskedastisity testing:

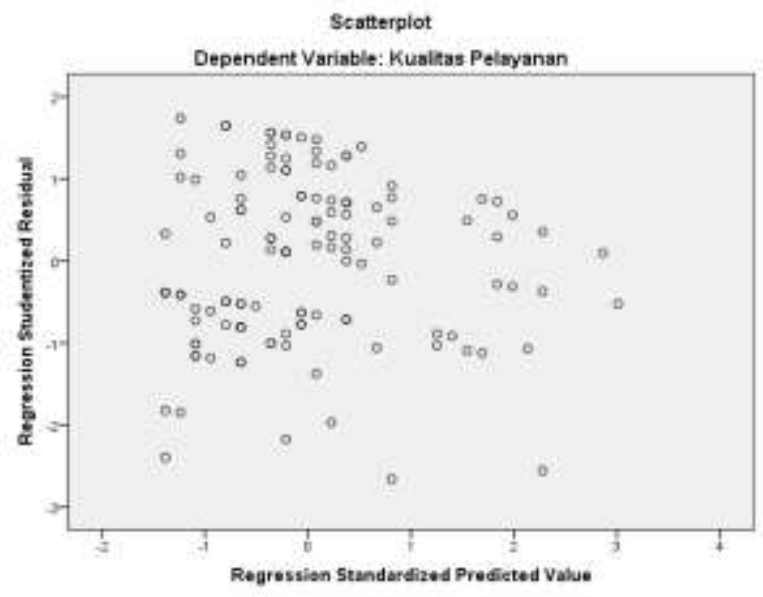

Fig 2. Scatterplot

According to the graph 2. Scatterplot graph, it can be noted that there is no obvious formation of the pattern, as well as the dots spread out above and below the number 0 on the Y axis, so it can be stored does not occur heteroskedastisity. 


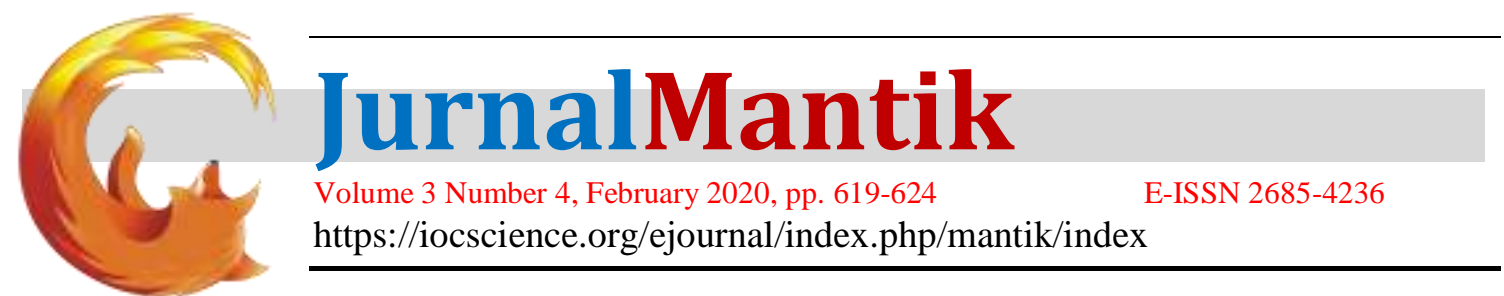

\section{c. Simple Regression Test}

Table 5. Regression Test

Coefficients $^{\mathrm{a}}$

\begin{tabular}{|c|c|c|c|c|c|c|}
\hline \multirow{2}{*}{\multicolumn{2}{|c|}{ Model }} & \multicolumn{2}{|c|}{$\begin{array}{c}\text { Unstandardized } \\
\text { Coefficients }\end{array}$} & \multirow{2}{*}{$\begin{array}{c}\text { Standardized } \\
\text { Coefficients } \\
\text { Beta }\end{array}$} & \multirow[b]{2}{*}{$\mathrm{t}$} & \multirow[b]{2}{*}{ Sig. } \\
\hline & & $\mathrm{B}$ & Std. Error & & & \\
\hline \multirow[t]{2}{*}{1} & (Constant) & 59,398 & 4,730 & & 12,557 & ,000 \\
\hline & Use of e-Filling & & ,093 & ,186 & 2,105 & 037 \\
\hline
\end{tabular}

a. Dependent Variable: Use of e-Filling

Based on the results of Table, There are Regression equations as follows:

$$
\mathrm{Y}=81,644-0,585 \mathrm{X}
$$

The value of 59.398 is a constant that the consistent value of the service quality variable (Y) is 59.398 , meaning if the use variable e-filling $(\mathrm{X})$ value is 0 , then the service quality variable $(\mathrm{Y})$ value is 59.398 . Meanwhile, the value of regression coefficient is negative of 0.195 , Meaning if there is an increment of one value or number in the variable use e-filling $(\mathrm{X})$ Then there will be a decrease in the service quality variable (Y) of 0.195

\section{d. Hypothesis Test}

Table 6. Hypothesis Test

Coefficients $^{\mathrm{a}}$

\begin{tabular}{|c|c|c|c|c|c|c|}
\hline \multirow{2}{*}{\multicolumn{2}{|c|}{ Model }} & \multicolumn{2}{|c|}{$\begin{array}{c}\text { Unstandardized } \\
\text { Coefficients } \\
\end{array}$} & \multirow{2}{*}{$\begin{array}{c}\text { Standardized } \\
\text { Coefficients } \\
\text { Beta }\end{array}$} & \multirow[b]{2}{*}{$\mathrm{t}$} & \multirow[b]{2}{*}{ Sig. } \\
\hline & & $\mathrm{B}$ & Std. Error & & & \\
\hline \multirow[t]{2}{*}{1} & (Constant) & 59,398 & 4,730 & & 12,557 &, 000 \\
\hline & Use of e-Filling & ,195 & ,093 & , 186 & 2,105 & 037 \\
\hline
\end{tabular}

a. Dependent Variable: Use of e-Filling

A partial test is performed to determine how large the effect of the variable is independent of the dependent variable. The calculated t value is 2.105 and the significance value is less than $5 \%$ or 0.05 that is 0.037 , it can be interpreted that the e-filling variable is positively affected by the quality of service and can be seen in the Significance column table (Sig.). Variable use of e-filling has a significance (sig. T) level of 0.037 . This value is less than $\alpha(0.05)$, hence $\mathrm{H} 0$ rejected and received $\mathrm{H} 1$ which means that the use of e-filling significantly affects the quality of service, with the increased use of e-filling with the availability of e-filling 24 hours, the quality of Service tax reporting provided by Fischus (government) is increasing. Taxpayers feel safe, comfortable and do not have to come to the Tax office to conduct their exposure reporting, so that the services provided by the Government can be used optimally and effectively. The results of this research in line with the research conducted by Saputra (2014:18) conducted in the agency PT. Indonesian railways and Gunawan (2017:15) at KPP Pratama Bandung Majalaya, the two studies stated that the application of e-filling affects the quality of tax Reporting Services. The existence of this e-filling can improve the quality of tax Reporting Services. The results in this research support the theory of the relation to the application of e-filing to the quality of service, that the existence of e-filing that can be delivered online, will facilitate the service of taxpayers, because the taxpayer does not have to Directly to the Tax Service office (Rosdiana and Irianto, 2011:30). 


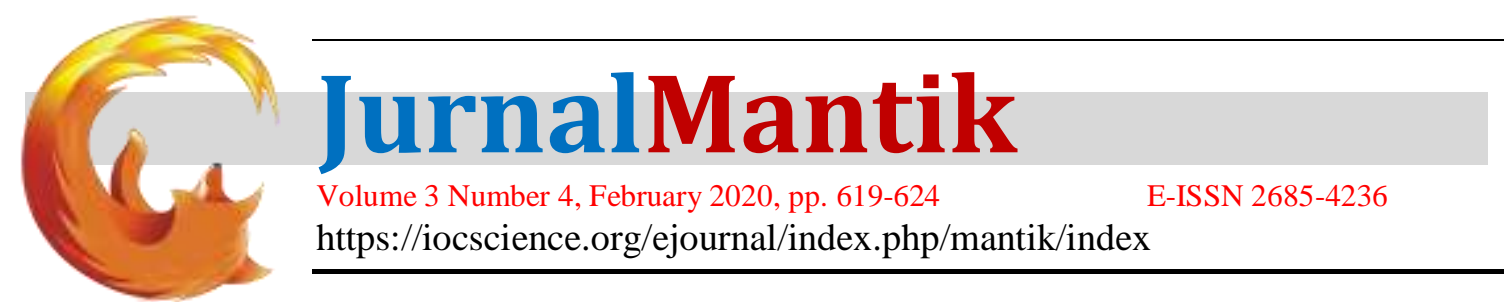

\section{Conclussion}

Based on the results and discussions in this study, it is important to note that the use of e-fliing positively affects the quality of the annual SPT Reporting service provided by Fiskus in this case is the Directorate General of Taxation More and more taxpayers use e-filling that can be used for 24 hours then the increasing quality of tax services provided by the Government, because the community believes and is comfortable to use e-filling as a medium for Report the annual SPT of taxation. The results of analysis of the SPSS of 0.037 and the significance value of the $<0.05$ then it is explained that the use of e-filing affects the quality of Reporting Services annual SPT. This e-Filling service is expected to improve the quality of service to the taxation reporting so as to increase the tax acceptance annually and can increase the compliance to the taxpayer to pay and report the exposure.

\section{Reference}

[1] Bastari, R.G. Nusantara Medcom Publishing. https://nusantara.medcom.id, 2018, retrieved February 10, 2020.

[2] Boedijono, Wicaksono, G, \& Puspita, Y et al. (2019). EFEKTIFITAS PENGELOLAAN DANA DESA UNTUK PEMBANGUNAN DAN PEMBERDAYAAN MASYARAKAT DESA DI KABUPATEN BONDOWOSO. Jurnal Riset Manajemen dan Bisnis (JRMB) Fakultas Ekonomi UNIAT, 4(1), 9 - 20

[3] Direktorat Jenderal Pajak. 2020. Laporan Kinerja Direktorat Jenderal Pajak. Jakarta.

[4] Fidel. 2010. Cara Mudah dan Praktis Memahami Masalah-Masalah Perpajakan. Jakarta: Muria Kencana.

[5] Ghozali, Imam. 2016. Aplikasi Analisis Multivariate Dengan Program SPSS. BP Undip, Semarang.

[6] Gunawan, M.C. 2017. Pengaruh Pelaksanaan E-Filing Terhadap Kualitas Pelayanan Pajak Serta Implikasinya Terhadap Kepuasan Wajib Pajak (Survei Pada Wajib Pajak Orang Pribadi di KPP Pratama Bandung Majalaya). Artikel Ilmiah. Universitas Komputer Indonesia Bandung.

[7] Hardiyansyah. 2011. Kualitas Pelayanan Publik (Konsep, Dimensi, Indikator, dan Implementasinya). Yogyakarta : Gava Media.

[8] Hentriwati, A.I, et al. 2018. Penggunaan E-Filing Oleh Wajib Pajak Dalam Upaya Meningkatkan Kualitas Pelayanan Perpajakan Di Kota Bandung. Jurnal Reformasi Administrasi 116 Vol. 5, No. 1.

[9] Kaihatu, T., et al. 2015. Manajemen Komplain. Yogyakarta: ANDI.

[10] Papadomichelaki, X. and Mentzas, G. 2011. E-GovQual: A Multiple item scale for assessing e-government service quality. Government Information Quarterly, [e-journal] 29 (1), 98-109.

[11] Peraturan Direktorat Jenderal Pajak. Perdirjen nomor PER-01/PJ/2017 tentang penyampaian SPT secara elektronik melalui $e$-filing.

[12] Peraturan Direktorat Jenderal Pajak. Perdirjen nomor PER-26/PJ/2012 tentang tata cara penerimaan dan pengolahan surat pemberitahuan.

[13] Permadi, Ardhi. Tribun Jatim Publishing, https://jatim.tribunnews.com 2018, retrieved February 10, 2020.

[14] Saputra. E.G 2014. Pengaruh Kualitas Teknologi Informasi Dan Penerapan E-Filing Terhadap Kualitas Pelayanan (Survei Pada Wajib Pajak Orang Pribadi Di Pt. Kereta Api Indonesia (Persero). Artikel Ilmiah. Universitas Komputer Indonesia Bandung.

[15] Susilo, D., Hidayat, R., Pamungkas, T. S., Wicaksono, G., Kusumaningrum, N. D., \& Asmandani, V. (2018). Total Quality Management On One-Stop Integrated Licensing Service In Indonesia: A Study Of Two Regional Governments In East Java. Int J Recent Sci Res. 9(12), pp.89-96.30122-30126

[15] Undang-Undang Nomor 28 Tahun 2007 tentang ketentuan umum dan tata cara perpajakan 